\title{
Evaluation of the effect of the addition of bioethanol to gas oil on coking diesel engine injector terminals
}

The article presents the results of empirical research and their analysis regarding the impact of diesel oil and diesel oil mixture with bioethanol on coking the test injector nozzles of the XUD9 engine from PSA. The research included three fuel deals: diesel fuel as the base fuel and diesel oil mix with ONE10 bioethanol (10\% bioethanol plus diesel oil (V/V)), ONE20 (20\% bioethanol plus diesel oil $(V / V))$. They were conducted on the basis of CEC PF-023 developed by CEC (Coordinating European Council). Each of the abovementioned fuels was tested using a new set of injectors. The propensity of the fuel for coking the injector tips was expressed as a percentage reduction in the air flow through the nozzles of each injector for the given sheer increments. The test result was the average percentage of airflow reduction for all nozzles at $0.1 \mathrm{~mm}$ spike increments and was measured according to ISO 4010 "Diesel engines. Calibrating nozzle, delay pintle type". The test results for individual atomizers of the above-mentioned test engine in the area of sediment formation from flowing fuel shown a lower tendency to coke the injectors using diesel fuel-bioethanol in comparison to the use of pure diesel oil. Based on the CEC PF-023 test, it can be noticed that the level of contamination of the tested injectors for ONE10 fuel is about $3 \%$ lower, and for ONE20 fuel is about 4\% lower than the level of pollution for diesel fuel.

Keywords: injection coking, combustion, fuel plant, environmental protection, engine diagnostics

\section{Introduction}

More and more stringent emission standards force the automotive industry to conduct research and seek technical solutions to ensure the least possible harmful effect of vehicles on the natural environment $[6,8,17,18]$.

For manufacturers of internal combustion engines, the main goal is to reduce noise, fuel consumption and emissions of toxic exhaust components - mainly from compression-ignition engines. One solution may be to supply combustion engines with fossil fuels with the addition of biofuel, which may be bioethanol [4]. The preparation of such a mixture and its application may reduce the emission of selected components of toxic fumes to the atmosphere $[3,16]$. The great advantage of this type of fuels is also their availability. Mainly due to the fact that parts of such a fuel mixture are produced from renewable sources, which are subject of regeneration $[2,7,14,21]$. One of the areas of research on bioethanol is its impact on the formation of the IDID (Internal Diesel Injector Deposit).

The internal injector deposition (IDID) phenomenon reduces the dynamics of internal injector working parts or their complete blocking. It may causes damage to important components of the engine's fuel supply system $[5,9,11$, 13].

Therefore, a test for coking injectors is very important in the preliminary processes of fuels intended for later commercial use. Thanks to it, we are able to determine the capping of nozzle tips that can cause problems with starting the engine, an uneven operation of the engine, uncontrolled changes in power and torque of the engine, and even its unexpected stop. As a consequence, it has an impact on the durability of the engine's fuel supply system and its operational parameters, such as the amount of fuel consumption or the level of emissions of selected toxic components of exhaust gases into the atmosphere $[12,15,20]$.

\section{Research purpose}

The aim of the research is to analyze and evaluate the coking of the ends of injectors a self-ignition engine powered with liquid fuels of alternative vegetable origin. Empirical studies were carried out for diesel oil $(\mathrm{ON})$ and a mixture of this fuel with bioethanol: ONE10 (10\% bioethanol plus diesel) and ONE20 (20\% bioethanol plus diesel). The tests were carried out on a test bench equipped with the XUD9A test engine used for this type of research by many research centres. The tests included assessing the degree of coking of atomizers in accordance with the CEC PF-023 procedure.

\section{Physicochemical properties of fuels}

For proper operation of the combustion engine, fuel with strictly defined physical and chemical properties is needed. Power systems have properties and constraints related to their construction and control, which are adapted to the appropriate physicochemical properties used in fuel engines $[1,10,19]$.

For empirical studies, diesel oil (ON) and bioethanol (E) were used as a component of the mixture. Table 1 presents the physicochemical properties of the basic fuels used in the tests.

Table 1. Basic physicochemical properties of engine fuels used in tests

\begin{tabular}{|l|c|c|c|}
\hline Parameter & Unit & Diesel fuel & $\begin{array}{c}\text { Bioetha- } \\
\text { nol }\end{array}$ \\
\hline Cetane number & - & 51.2 & 10 \\
\hline Heat value & $\mathrm{MJ} / \mathrm{kg}$ & 42.4 & 27.3 \\
\hline Density at $15^{\circ} \mathrm{C}$ & $\mathrm{g} / \mathrm{cm}^{3}$ & 0.836 & 0,795 \\
\hline Kinematic viscosity & $\mathrm{mm}^{2} / \mathrm{s}$ & 2.92 & 0.93 \\
\hline Surface tension & $\mathrm{N} / \mathrm{m}$ & $3,63 \cdot 10^{-2}$ & - \\
\hline Flash-point & ${ }^{\circ} \mathrm{C}$ & 13 & - \\
\hline Cloud point & ${ }^{\circ} \mathrm{C}$ & -16 & - \\
\hline $\begin{array}{l}\text { The temperature of blocking } \\
\text { the cold filter }\end{array}$ & ${ }^{\circ} \mathrm{C}$ & -34 & - \\
\hline
\end{tabular}


Table 1 cont.

\begin{tabular}{|c|c|c|c|}
\hline Parameter & Unit & Diesel fuel & $\begin{array}{l}\text { Bioetha- } \\
\text { nol }\end{array}$ \\
\hline \multirow{4}{*}{$\begin{array}{l}\text { Average elementary composi- } \\
\text { tion } \\
\text { C } \\
\mathrm{H} \\
\mathrm{O}\end{array}$} & \multirow[t]{4}{*}{$\%$} & & \\
\hline & & 87.3 & 52.2 \\
\hline & & 12.7 & 13.7 \\
\hline & & 0 & 34.1 \\
\hline Sulfur content $\mathrm{S}$ & $\mathrm{mg} / \mathrm{kg}$ & 8 & - \\
\hline Water content & $\mathrm{mg} / \mathrm{kg}$ & 43.5 & - \\
\hline Solid impurities content & $\mathrm{mg} / \mathrm{kg}$ & 4 & - \\
\hline $\begin{array}{l}\text { Coke residue in a } 10 \% \text { distilla- } \\
\text { tion residue }\end{array}$ & $\%(\mathrm{~m} / \mathrm{m})$ & 0.02 & - \\
\hline $\begin{array}{l}\text { Research on the corrosive } \\
\text { effect on copper plates }\end{array}$ & & 1 & - \\
\hline
\end{tabular}

In addition to diesel fuel, a test mix of this fuel with dehydrated bioethanol with the following composition was also used:

- ONE10 - 89\% ON + 0.4\% Rokanol O3 + 0.6\% Rokok L3S $+10 \%$ Bioethanol (E-diesel),

- ONE20 - 78\% ON + 1\% Rokanol O3 + 1\% Rokanol L3S + 20\% Bioethanol (E-diesel).

The examined physicochemical properties of the abovementioned mixtures are presented in Table 2.

Table 2. Selected physicochemical properties of mixtures

\begin{tabular}{|l|c|c|c|}
\hline \multirow{2}{*}{ Parameter } & \multirow{2}{*}{ Unit } & \multicolumn{2}{|c|}{ Value } \\
\cline { 3 - 4 } & & ONE10 & ONE20 \\
\hline $\begin{array}{l}\text { Flash-point } \\
\text { (open crucible) }\end{array}$ & ${ }^{\circ} \mathrm{C}$ & 34 & 32 \\
\hline Cloud point & & & $<23$ \\
\hline Density at $15^{\circ} \mathrm{C}$ & ${ }^{\circ} \mathrm{C}$ & $<+23$ & $<+23$ \\
\hline Kinematic viscosity at $40^{\circ} \mathrm{C}$ & $\mathrm{kg}^{2} / \mathrm{s}$ & 832.5 & 828.2 \\
\hline
\end{tabular}

Blends of diesel oil with bioethanol: ONE10 (10\% bioethanol plus diesel) and ONE20 (20\% bio-ethanol plus diesel) can be, due to their physicochemical properties, substitute fuels for diesel.

\section{Research stand and test method}

The research stand included:

- XUD9A research engine,

- Schenck W400 electromagnetic brake with a controller enabling constant engine speed,

- Electronic servomotor for setting the injection pump,

- Air consumption measurement system consisting of a laminar flow meter type E 7035 and a pressure difference meter type MK1,

- Standard systems for measuring speed, torque, fuel consumption, oil and coolant temperature, and other devices that meet the requirements of $\mathrm{PN}-88 / \mathrm{S}-02005$,

- Device for determining injector opening pressure from L. Hartridge Ltd,

- Device for measuring atomizer throughput in accordance with ISO 4010.

The empirical studies of coking of injectors were carried out on a test stand at the Vehicles Institute, Warsaw University of Technology, which is shown in Fig. 1. The sediment formation was evaluated on the basis of CEC PF-023 tests using a new set of injectors for each fuel tested.
The scope of the measurements included the assessment of the degree of coking of the nozzles in accordance with the CEC PF-023 procedure, based on the examination of the propensity to contaminate fuel atomizers. LUCAS RDNO 6887 D 03 CFR type sprayers were used for testing. The tests were carried out in accordance with the abovementioned standard and in the following order:

- measurement of the throughput of brand new sprays in accordance with ISO 4010,

- setting the injector opening pressure in accordance with the requirements of the CEC PF-023 procedure and mounting them on the engine,

- performing a ten-hour test sample in accordance with the CEC PF-023 procedure,

- capacity measurement of disassembled and contaminated atomizers in accordance with ISO 4010.

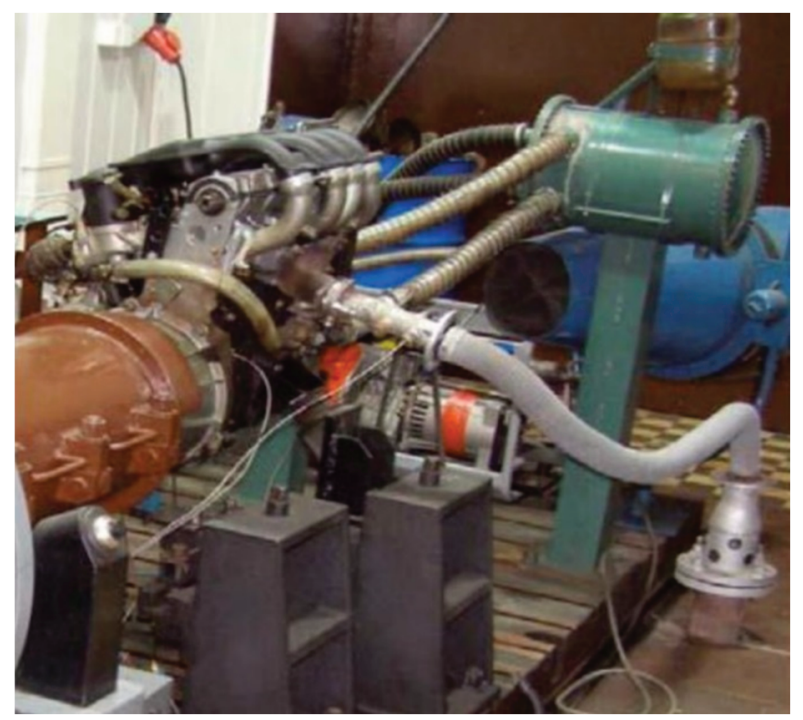

Fig. 1. The test stand equipped with XUD9A engine [12]

The propensity of fuel for cooking the injector tips is expressed as a percentage reduction in the air flow through the nozzles of each of the 4 injectors for a given needle lift value.

The test result is the mean value of the percentage airflow reduction for all 4 nozzles at a needle lift of $0.1 \mathrm{~mm}$.

\section{Research results}

The tendency of fuels to form sediments is determined by measuring the air flow through the nozzles before and after the test. The result is expressed as the average percentage decrease in air flow through the nozzles. The results of flow rate tests through nozzles are presented in Tables 3-11 and graphically in Figures 2-7.

Table 3. Results of spray flow rate measurements before the test - ON

\begin{tabular}{|c|c|c|c|c|}
\hline $\begin{array}{c}\text { uplift } \\
{[\mathrm{mm}]}\end{array}$ & $\begin{array}{c}\text { nozzle 1 } \\
{\left[\mathrm{cm}^{3} / \mathrm{min}\right]}\end{array}$ & $\begin{array}{c}\text { nozzle 2 } \\
{\left[\mathrm{cm}^{3} / \mathrm{min}\right]}\end{array}$ & $\begin{array}{c}\text { nozzle 3 } \\
{\left[\mathrm{cm}^{3} / \mathrm{min}\right]}\end{array}$ & $\begin{array}{c}\text { nozzle 4 } \\
{\left[\mathrm{cm}^{3} / \mathrm{min}\right]}\end{array}$ \\
\hline 0.05 & 201 & 200 & 217 & 225 \\
\hline 0.1 & 250 & 248 & 248 & 258 \\
\hline 0.2 & 255 & 283 & 267 & 283 \\
\hline 0.3 & 303 & 367 & 312 & 317 \\
\hline 0.4 & 417 & 500 & 443 & 432 \\
\hline 0.5 & 800 & 850 & 817 & 867 \\
\hline
\end{tabular}


Evaluation of the effect of the addition of bioethanol to gas oil on coking diesel engine injector terminals

Table 4. Results of spray flow rate measurements after the test - ON

\begin{tabular}{|c|c|c|c|c|}
\hline $\begin{array}{c}\text { uplift } \\
{[\mathrm{mm}]}\end{array}$ & $\begin{array}{c}\text { nozzle 1 } \\
{\left[\mathrm{cm}^{3} / \mathrm{min}\right]}\end{array}$ & $\begin{array}{c}\text { nozzle 2 } \\
{\left[\mathrm{cm}^{3} / \mathrm{min}\right]}\end{array}$ & $\begin{array}{c}\text { nozzle 3 } \\
{\left[\mathrm{cm}^{3} / \mathrm{min}\right]}\end{array}$ & $\begin{array}{c}\text { nozzle 4 } \\
{\left[\mathrm{cm}^{3} / \mathrm{min}\right]}\end{array}$ \\
\hline 0.05 & 93 & 90 & 120 & 110 \\
\hline 0.1 & 133 & 125 & 128 & 130 \\
\hline 0.2 & 147 & 142 & 175 & 173 \\
\hline 0.3 & 183 & 200 & 212 & 223 \\
\hline 0.4 & 283 & 282 & 287 & 375 \\
\hline 0.5 & 567 & 647 & 533 & 763 \\
\hline
\end{tabular}

Table 5. Calculation results $-\mathrm{ON}$

\begin{tabular}{|c|c|c|c|c|c|}
\hline $\begin{array}{c}\text { uplift } \\
{[\mathrm{mm}]}\end{array}$ & $\begin{array}{c}\mathrm{R} 1 \\
{\left[\mathrm{~cm}^{3} / \mathrm{min}\right]}\end{array}$ & $\begin{array}{c}\mathrm{R} 2 \\
{\left[\mathrm{~cm}^{3} / \mathrm{min}\right]}\end{array}$ & $\begin{array}{c}\mathrm{R} 3 \\
{\left[\mathrm{~cm}^{3} / \mathrm{min}\right]}\end{array}$ & $\begin{array}{c}\mathrm{R} 4 \\
{\left[\mathrm{~cm}^{3} / \mathrm{min}\right]}\end{array}$ & $\begin{array}{c}\text { average } \\
{[\%]}\end{array}$ \\
\hline 0.05 & $53.6 \%$ & $55.2 \%$ & $44.6 \%$ & $51.1 \%$ & $51.1 \%$ \\
\hline $\mathbf{0 . 1}$ & $46.7 \%$ & $49.5 \%$ & $48.3 \%$ & $49.7 \%$ & $\mathbf{4 8 . 5 \%}$ \\
\hline 0.2 & $42.5 \%$ & $50.0 \%$ & $34.4 \%$ & $38.8 \%$ & $41.4 \%$ \\
\hline 0.3 & $39.6 \%$ & $45.5 \%$ & $32.1 \%$ & $29.5 \%$ & $36.6 \%$ \\
\hline 0.4 & $32.0 \%$ & $43.7 \%$ & $35.4 \%$ & $13.1 \%$ & $31.0 \%$ \\
\hline 0.5 & $29.2 \%$ & $23.8 \%$ & $34.7 \%$ & $11.9 \%$ & $24.9 \%$ \\
\hline
\end{tabular}

Table 6. Results of spray flow rate measurements before the test - ONE10

\begin{tabular}{|c|c|c|c|c|}
\hline $\begin{array}{c}\text { uplift } \\
{[\mathrm{mm}]}\end{array}$ & $\begin{array}{c}\text { nozzle1 } \\
{\left[\mathrm{cm}^{3} / \mathrm{min}\right]}\end{array}$ & $\begin{array}{c}\text { nozzle2 } \\
{\left[\mathrm{cm}^{3} / \mathrm{min}\right]}\end{array}$ & $\begin{array}{c}\text { nozzle 3 } \\
{\left[\mathrm{cm}^{3} / \mathrm{min}\right]}\end{array}$ & $\begin{array}{c}\text { nozzle 4 } \\
{\left[\mathrm{cm}^{3} / \mathrm{min}\right]}\end{array}$ \\
\hline 0.05 & 165 & 198 & 215 & 223 \\
\hline 0.1 & 251 & 252 & 249 & 251 \\
\hline 0.2 & 253 & 281 & 264 & 281 \\
\hline 0.3 & 301 & 363 & 309 & 314 \\
\hline 0.4 & 413 & 496 & 439 & 428 \\
\hline 0.5 & 799 & 812 & 819 & 859 \\
\hline
\end{tabular}

Table 7. Results of spray flow rate measurements after the test - ONE10

\begin{tabular}{|c|c|c|c|c|}
\hline $\begin{array}{c}\text { uplift } \\
{[\mathrm{mm}]}\end{array}$ & $\begin{array}{c}\text { nozzle 1 } \\
{\left[\mathrm{cm}^{3} / \mathrm{min}\right]}\end{array}$ & $\begin{array}{c}\text { nozzle 2 } \\
{\left[\mathrm{cm}^{3} / \mathrm{min}\right]}\end{array}$ & $\begin{array}{c}\text { nozzle 3 } \\
{\left[\mathrm{cm}^{3} / \mathrm{min}\right]}\end{array}$ & $\begin{array}{c}\text { nozzle 4 } \\
{\left[\mathrm{cm}^{3} / \mathrm{min}\right]}\end{array}$ \\
\hline 0.05 & 84 & 90 & 115 & 108 \\
\hline 0.1 & 137 & 134 & 132 & 136 \\
\hline 0.2 & 148 & 145 & 177 & 175 \\
\hline 0.3 & 185 & 202 & 214 & 226 \\
\hline 0.4 & 286 & 277 & 320 & 339 \\
\hline 0.5 & 584 & 599 & 642 & 689 \\
\hline
\end{tabular}

Table 8. Calculation results - ONE10

\begin{tabular}{|c|c|c|c|c|c|}
\hline $\begin{array}{c}\text { uplift } \\
{[\mathrm{mm}]}\end{array}$ & $\begin{array}{c}\mathrm{R} 1 \\
{\left[\mathrm{~cm}^{3} / \mathrm{min}\right]}\end{array}$ & $\begin{array}{c}\mathrm{R} 2 \\
{\left[\mathrm{~cm}^{3} / \mathrm{min}\right]}\end{array}$ & $\begin{array}{c}\mathrm{R} 3 \\
{\left[\mathrm{~cm}^{3} / \mathrm{min}\right]}\end{array}$ & $\begin{array}{c}\mathrm{R} 4 \\
{\left[\mathrm{~cm}^{3} / \mathrm{min}\right]}\end{array}$ & $\begin{array}{c}\text { average } \\
{[\%]}\end{array}$ \\
\hline 0.05 & $49.1 \%$ & $54.8 \%$ & $46.4 \%$ & $51.6 \%$ & $50.5 \%$ \\
\hline $\mathbf{0 . 1}$ & $45.5 \%$ & $46.8 \%$ & $47.0 \%$ & $45.7 \%$ & $\mathbf{4 6 . 3 \%}$ \\
\hline 0.2 & $41.4 \%$ & $48.3 \%$ & $33.1 \%$ & $37.7 \%$ & $40.1 \%$ \\
\hline 0.3 & $38.4 \%$ & $44.4 \%$ & $30.8 \%$ & $28.1 \%$ & $35.4 \%$ \\
\hline 0.4 & $30.7 \%$ & $44.0 \%$ & $27.2 \%$ & $20.8 \%$ & $30.7 \%$ \\
\hline 0.5 & $26.9 \%$ & $26.2 \%$ & $21.7 \%$ & $19.8 \%$ & $23.6 \%$ \\
\hline
\end{tabular}

Table 9. Results of spray flow rate measurements before the test - ONE20

\begin{tabular}{|c|c|c|c|c|}
\hline $\begin{array}{c}\text { uplift } \\
{[\mathrm{mm}]}\end{array}$ & $\begin{array}{c}\text { nozzle 1 } \\
{\left[\mathrm{cm}^{3} / \mathrm{min}\right]}\end{array}$ & $\begin{array}{c}\text { nozzle 2 } \\
{\left[\mathrm{cm}^{3} / \mathrm{min}\right]}\end{array}$ & $\begin{array}{c}\text { nozzle 3 } \\
{\left[\mathrm{cm}^{3} / \mathrm{min}\right]}\end{array}$ & $\begin{array}{c}\text { nozzle 4 } \\
{\left[\mathrm{cm}^{3} / \mathrm{min}\right]}\end{array}$ \\
\hline 0.05 & 201 & 200 & 217 & 225 \\
\hline 0.1 & 250 & 248 & 248 & 258 \\
\hline 0.2 & 255 & 283 & 267 & 283 \\
\hline 0.3 & 303 & 367 & 312 & 317 \\
\hline 0.4 & 417 & 500 & 443 & 432 \\
\hline 0.5 & 800 & 850 & 817 & 867 \\
\hline
\end{tabular}

Table 10. Results of spray flow rate measurements after the test - ONE20

\begin{tabular}{|c|c|c|c|c|}
\hline $\begin{array}{c}\text { uplift } \\
{[\mathrm{mm}]}\end{array}$ & $\begin{array}{c}\text { nozzle } 1 \\
{\left[\mathrm{~cm}^{3} / \mathrm{min}\right]}\end{array}$ & $\begin{array}{c}\text { nozzle 2 } \\
{\left[\mathrm{cm}^{3} / \mathrm{min}\right]}\end{array}$ & $\begin{array}{c}\text { nozzle 3 } \\
{\left[\mathrm{cm}^{3} / \mathrm{min}\right]}\end{array}$ & $\begin{array}{c}\text { nozzle 4 } \\
{\left[\mathrm{cm}^{3} / \mathrm{min}\right]}\end{array}$ \\
\hline 0.05 & 100 & 92 & 120 & 110 \\
\hline 0.1 & 140 & 135 & 135 & 143 \\
\hline 0.2 & 156 & 150 & 175 & 173 \\
\hline 0.3 & 198 & 205 & 212 & 223 \\
\hline 0.4 & 293 & 301 & 287 & 375 \\
\hline 0.5 & 645 & 647 & 634 & 663 \\
\hline
\end{tabular}

Table 11. Calculation results - ONE20

\begin{tabular}{|c|c|c|c|c|c|}
\hline $\begin{array}{c}\text { uplift } \\
{[\mathrm{mm}]}\end{array}$ & $\begin{array}{c}\mathrm{R} 1 \\
{\left[\mathrm{~cm}^{3} / \mathrm{min}\right]}\end{array}$ & $\begin{array}{c}\mathrm{R} 2 \\
{\left[\mathrm{~cm}^{3} / \mathrm{min}\right]}\end{array}$ & $\begin{array}{c}\mathrm{R} 3 \\
{\left[\mathrm{~cm}^{3} / \mathrm{min}\right]}\end{array}$ & $\begin{array}{c}\mathrm{R} 4 \\
{\left[\mathrm{~cm}^{3} / \mathrm{min}\right]}\end{array}$ & $\begin{array}{c}\text { average } \\
{[\%]}\end{array}$ \\
\hline 0.05 & $50.2 \%$ & $54.0 \%$ & $44.6 \%$ & $51.1 \%$ & $50.0 \%$ \\
\hline $\mathbf{0 . 1}$ & $44.0 \%$ & $45.5 \%$ & $45.6 \%$ & $44.6 \%$ & $\mathbf{4 4 . 9 \%}$ \\
\hline 0.2 & $38.8 \%$ & $47.1 \%$ & $34.4 \%$ & $38.8 \%$ & $39.8 \%$ \\
\hline 0.3 & $34.7 \%$ & $44.1 \%$ & $32.1 \%$ & $29.5 \%$ & $35.1 \%$ \\
\hline 0.4 & $29.7 \%$ & $39.8 \%$ & $35.4 \%$ & $13.1 \%$ & $29.5 \%$ \\
\hline 0.5 & $19.4 \%$ & $23.8 \%$ & $22.4 \%$ & $23.5 \%$ & $22.3 \%$ \\
\hline
\end{tabular}

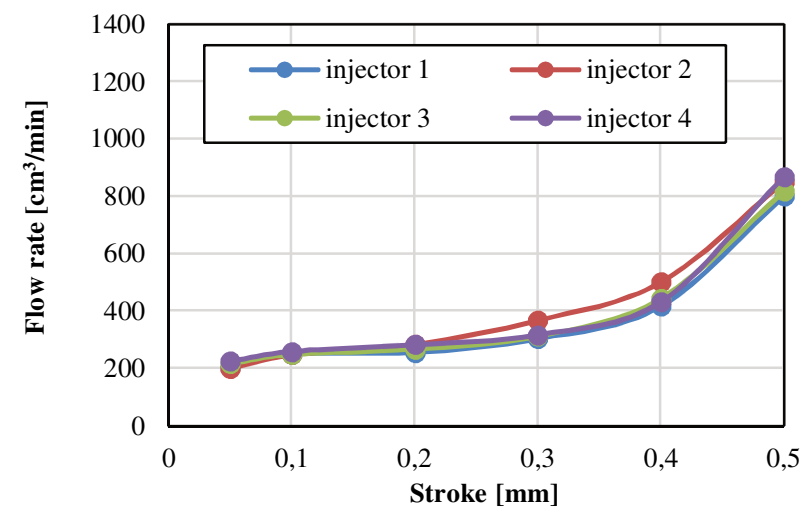

Fig. 2. The flow rate through nozzles before the test for $\mathrm{ON}$ fuel

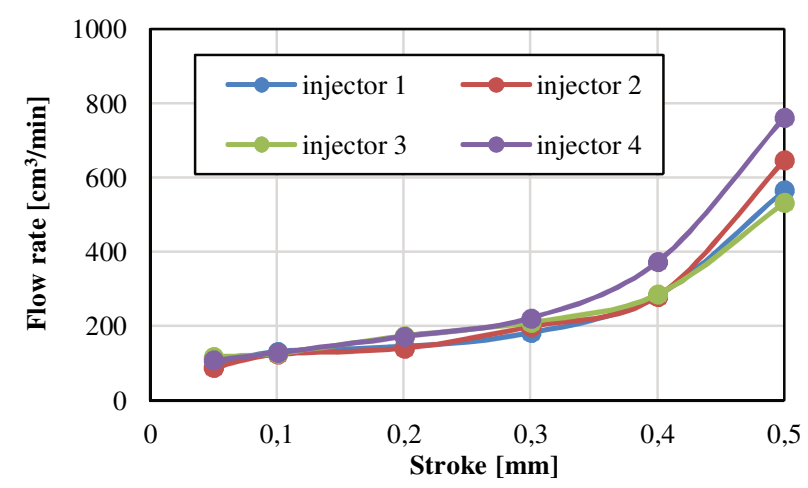

Fig. 3.The flow rate through nozzles after the test for ON fuel

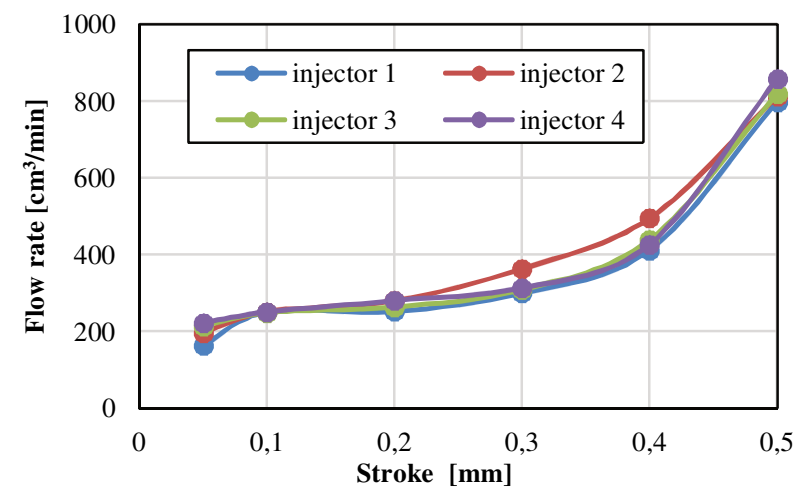

Fig. 4.The flow rate through nozzles before the test for ONE10 fuel 


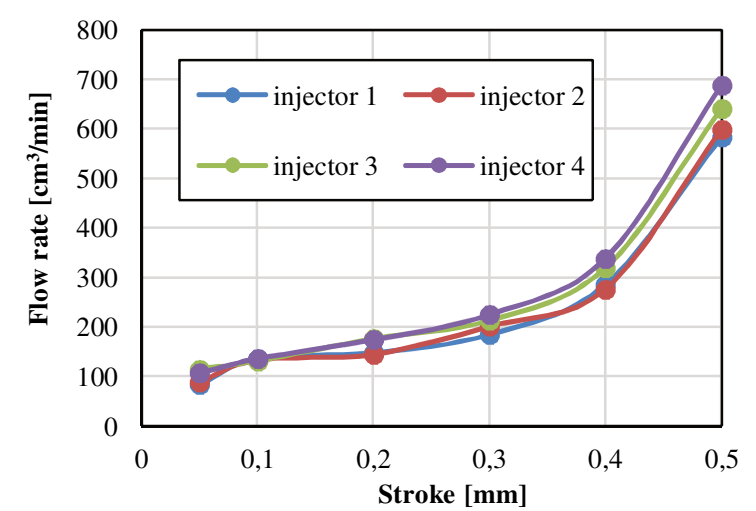

Fig. 5.The flow rate through nozzles after the test for ONE10 fuel

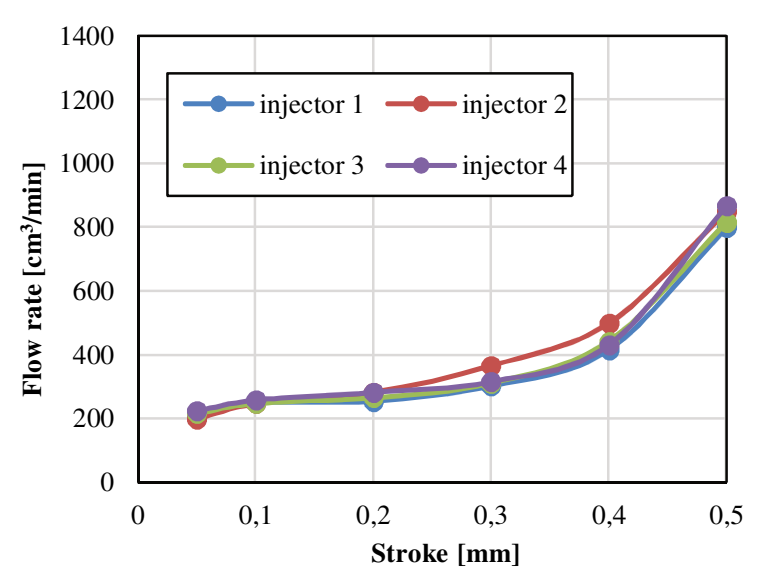

Fig. 6. The flow rate through nozzles before the test for ONE20 fuel

\section{Conclusions}

The tests showed a lower tendency to coke the injectors using diesel fuel-bioethanol in comparison to the use of pure diesel oil.

Based on the CEC PF-023 test, it can be noticed that the level of contamination of the tested injectors (at a heel of $0.1 \mathrm{~mm}$ ) for ONE10 fuel is about 3\% lower than the level of diesel injector contamination.

The level of injector coking for ONE20 fuel is about 4\% lower than the level of pollution for diesel fuel.

Lower susceptibility to coking the injectors using a mixture of bioethanol and diesel oil compared to the diesel oil itself gives the possibility of reducing deposits at the ends of the injectors.

Surface coking at the tip of the needle tip - the sprayer and nozzle openings reduce or block the flow of fuel through the injector and change the spraying quality and microstructure of the sprayed stream. In addition, the con-

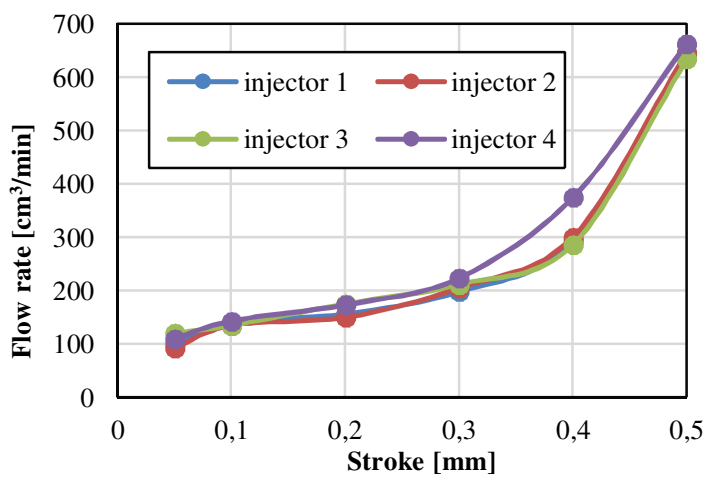

Fig. 7. The flow rate through nozzles after the test for ONE20 fuel

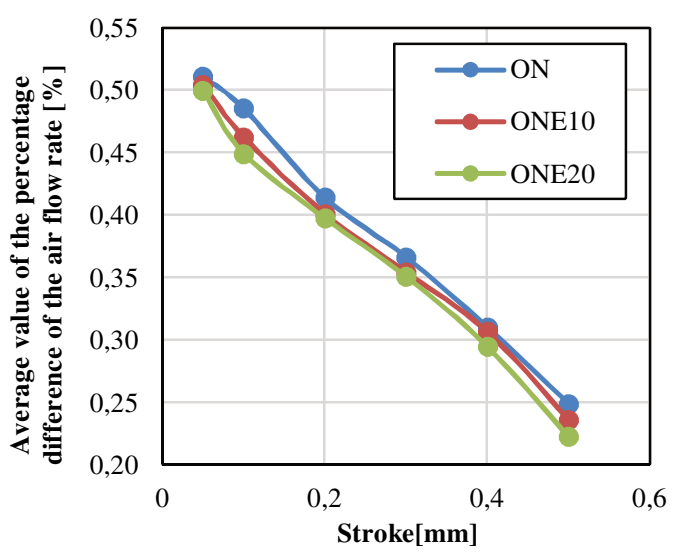

Fig. 8. The average value of the difference in the air flow rate through injectors obtained in the CEC test PF- 023 while covering the test engine with three fuels

tamination of the injector tip reduces the distance of the diffusion flame to the injector causing heat exchange between the deposits and deposits created in the sprayer, not with the spray of fuel creating a rich fuel-air mixture, which causes a slower combustion process and increased particulate matter emission.

In summary, sediments have a negative impact on the operation of injectors in CI engines. The problem is important from the point of view of their durability and reliability because their components have small dimensions, low mass and are manufactured with high accuracy using very advanced techniques. In contrast, the tolerance of performance of individual cooperating elements has a direct impact on the time and size of injection doses. All this indicates that the tendency to injectors coking is a considerable problem, which can be partially eliminated with the addition of bioethanol to diesel oil.

\section{Nomenclature}

ON diesel oil

ONE10 10\% bioethanol + diesel

ONE20 20\% bioethanol + diesel

E bioethanol

$\mathrm{R} 1$ injector 1
R2 injector 2

R3 injector 3

R4 injector 4

IDID Internal Diesel Injector Deposit 


\section{Bibliography}

[1] BEDNARSKI, M., SAMOILENKO, D., ORLIŃSKI, P., SIKORA M. Evaluation of the diesel engine parameters after regeneration of its fuel delivery system. Transp. Means Proc. Int. Conf. 2017, 2, 547-553.

[2] DHARMA, S., ONG, H.C., MASJUKI, H.H. et al. An overview of engine durability and compatibility using biodieselbioethanol-diesel blends in compression-ignition engines. Energy Convers. Manag. 2016, 128, 66-81.

[3] HERREROS, J.M., SCHROER, K., SUKJIT, E., TSOLAKIS, A. Extending the environmental benefits of ethanoldiesel blends through DGE incorporation. Appl. Energy. 2015, 146, 335-343.

[4] KHAN, Z., DWIVEDI, A.K. Fermentation of biomass for production of ethanol: a review. Univers. J. Environ. Res. Technol. 2013, 3, 1-13.

[5] KIM, Y., SONG, H. Effects of injector design parameter on nozzle coking in diesel engines. J. ILASS-Korea. 2012, 17, 140-145.

[6] KRUCZYŃSKI, S., GIS, W., ORLIŃSKI, P., SIKORA, M. Influence of the use of ethanol fuel on selected parameters of the gasoline engine. IOP Conf. Ser. Mater. Sci. Eng. 2018, 421, 042041.

[7] KUSZEWSKI, H. Experimental investigation of the effect of ambient gas temperature on the autoignition properties of ethanol-diesel fuel blends. Fuel. 2018, 214, 26-38.

[8] LASOCKI, J., BEDNARSKI, M., SIKORA, M. Simulation of ammonia combustion in dual-fuel compression-ignition engine. IOP Conf. Ser. Earth Environ. Sci. 2019, 214, 012081.

[9] LEE, C.-W., REITZ, R.D., KURTZ, E. The impact of engine design constraints on diesel combustion system size scaling. 2010, SAE Technical Paper 2010-01-0180.

[10] MAZURUK, P., WOJS, M., ORLIŃSKI, P., SIKORA, M. Detection of damage to the power supply system of diesel engine under field conditions. Combustion Engines. 2017, 56, 159-163.

[11] MONTANARO, A., ALLOCCA, L. Impact of the nozzle coking on spray formation for diesel injectors. 2013, SAE Technical Paper 2013-01-2546.

Piotr Orliński, DSc., DEng. - Faculty of Automotive and Construction Machinery Engineering, Warsaw University of Technology.

e-mail: piotr.orlinski@pw.edu.pl

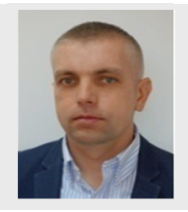

Marcin K. Wojs, DEng. - Faculty of Automotive and Construction Machinery Engineering, Warsaw University of Technology.

e-mail:marcin.wojs@pw.edu.pl
[12] ORLIŃSKI, P., WOJS, M., MAZURUK, P., KRUCZYŃSKI, P. Influence of biodiesel on injection nozzle coking. Combustion Engines. 2015, 162(3), 599-607.

[13] RISBERG, P.A., ADLERCREUTZ, L., GÓMEZ AGUILERA, M. et al. Development of a heavy duty nozzle coking test. 2013, SAE Technical Paper 2013-01-2674.

[14] SAKTHIVEL, P., SUBRAMANIAN, K.A., MATHAI, R., Indian scenario of ethanol fuel and its utilization in automotive transportation sector. Resour. Conserv. Recycl. 2018, 132, 102-120.

[15] SCHUCKERT, S., WACHTMEISTER, G. Characteristics of control piston motion and pressure inside of a common rail diesel injector. Proc. ILASS-Europe 2017. 28th Conf. Liq. At. Spray Syst., Valencia 2017.

[16] SHAHIR, S.A., MASJUKI, H.H., KALAM, M.A. et al. Performance and emission assessment of diesel-biodieselethanol/bioethanol blend as a fuel in diesel engines: A review. Renew. Sustain. Energy Rev. 2015, 48, 62-78.

[17] SIKORA, M., BEDNARSKI, M., LASOCKI, J. et al. Ammonia as a fuel for spark-ignition engines. Zesz. Nauk. Inst. Pojazdów/Politech. Warsz. 2017, 5(114).

[18] SIKORA, M., ORLIŃSKI, P., BEDNARSKI, M., WOJS, $M$. Evaluation of the heat release rate in the combustion chamber of the self-ignition engine powered by sunflower methyl esters. Proc. Inst. Veh. 2018, 1(115)/201, 27-34.

[19] STANIK, W., JAKÓBIEC, J., WĄDRZYK, M. Design factors affecting the formation of the air-fuel mixture and the process of combustion in compression ignition engines. Combustion Engines. 2013, 154(3), 40-50.

[20] STANIK, W., MAZANEK, A., JAKÓBIEC, J. Badania oleju napędowego zawierającego 7\%(v/v) FAME i dodatek cetanowy w zakresie oceny użytkowej i czystości wtryskiwaczy czopikowych. Combustion Engines. 2015, 54(3), 933-943.

[21] SUHAIMI, H., ADAM, A., MRWAN, A.G. et al. Analysis of combustion characteristics, engine performances and emissions of long-chain alcohol-diesel fuel blends. Fuel. 2018, 220, 682-691.

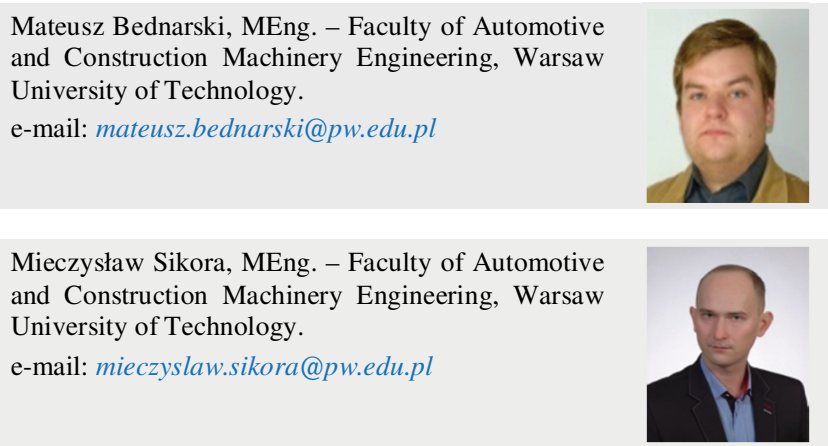
University of Technology.

rieczslawsikora@p wedu.pl

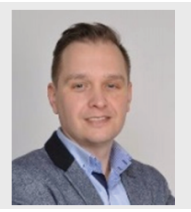

